\title{
Reactivity of 1,1-Dithiolato Ni(II) and Co(II) with Phenylthiourea, Chlorophenylthiourea and Bis(diphenylphosphinothioyl)methane
}

\author{
Aref A. M. Aly*, Mostafa M. Kamal, Mahmoud S. El-Meligy, and Asma I. El-Said \\ Chemistry Department, Faculty of Science, Assiut University, Assiut, Egypt \\ Z. Naturforsch. 42b, 233-237 (1987); received September 15, 1986 \\ Phenylthiourea, Chlorophenylthiourea, 1,1-Dithiolato Ni(II) \\ The following mixed ligand complexes were synthesized and characterized: $\mathrm{Co}(\mathrm{Phdtcz})_{2}(\mathrm{Phtu})_{2}$, \\ $\mathrm{Co}(\mathrm{Phdtcz})_{2}(\mathrm{Clphtu})_{2}, \mathrm{Co}(\mathrm{Phdtcz})_{2}(\mathrm{dtm}), \mathrm{Ni}\left(\mathrm{Et}_{2} \mathrm{dtc}\right)_{2}(\mathrm{dtm}), \mathrm{Ni}(\mathrm{Phdtc})_{2}(\mathrm{dtm})$, \\ $\mathrm{Ni}(p \text {-Toluiddtc })_{2}(\mathrm{dtm}), \mathrm{Ni}(\alpha \text {-naphdtc })_{2}(\mathrm{dtm})$, and $\mathrm{Ni}(\mathrm{Phdtcz})\left(\mathrm{Et}_{2} \mathrm{dtc}\right)$; where Phdtcz $=$ phe- \\ nyldithiocarbazate, $\mathrm{Et}_{2} \mathrm{dtc}=$ diethyldithiocarbamate, Phdtc $=$ phenyldithiocarbamate, \\ $p$-Toluiddtc $=p$-toluidinedithiocarbamate, $\alpha$-naphdtc $=\alpha$-naphthyldithiocarbamate, Phtu $=$ \\ phenylthiourea, Clphtu = chlorophenylthiourea, and $\mathrm{dtm}=$ bis(diphenylphosphinothioyl)- \\ methane. Electronic and IR spectra, magnetic, conductivity and X-ray powder diffraction meas- \\ urements were carried out. The $\mathrm{Ni}$ (II) and $\mathrm{Co}(\mathrm{II})$ complexes are suggested to be square planar \\ and octahedral, respectively. The biological activity of the complexes was also tested.
}

\section{Introduction}

Current interest in the preparation of dithiocarbazate and dithiocarbamate complexes of transition metals and their reactivity with different Lewis bases [1-3] has prompted this report on the interaction of some dithiocarbazato and dithiocarbamato complexes of $\mathrm{Co}(\mathrm{II})$ and $\mathrm{Ni}(\mathrm{II})$ with sulphur containing ligands including phenylthiourea $\left(\mathrm{PhNHCSNH}_{2}\right)$, chlorophenylthiourea $\left(\mathrm{ClPhNHCSNH}_{2}\right)$, and bis(diphenylphosphinothioyl)methane $\left[\mathrm{Ph}_{2} \mathrm{P}(\mathrm{S}) \mathrm{CH}_{2} \mathrm{P}(\mathrm{S}) \mathrm{Ph}_{2}\right]$. The last ligand and other related compounds and their complexes were the subject of recent papers [4-6].

\section{Results and Discussion}

The complexes (Table I) are obtained readily from the interaction of dithiocarbazato and dithiocarbamato $\mathrm{Co}(\mathrm{II})$ with the respective ligands. The compounds are fairly soluble in most of the common organic solvents. Mixed ligand complexes with dtm are crystalline solids. The conductivity measurements of $\mathrm{Co}$ (II) mixed ligand complexes of Phtu and Clphtu in DMF (complexes 1 and 2) reveal that they are essentially non-electrolytes. Complexes of $\mathrm{Co}(\mathrm{II})$ and $\mathrm{Ni}(\mathrm{II})$ with bis(diphenylphosphinothioyl)methane (compounds 3-7) display conductivity values much lower than those expected for 1:1 electrolytes [7].

\footnotetext{
* Reprint requests to Dr. A. A. M. Aly.

Verlag der Zeitschrift für Naturforschung, D-7400 Tübingen 0340-5087/87/0200-0233/\$01.00/0
}

All Co(II) dithiocarbazato mixed ligand complexes exhibit magnetic moment values which seem to fall in the range expected for spin only octahedral $\mathrm{Co}(\mathrm{II})$ complexes [8]. Dithiocarbamato Ni(II) mixed ligand complexes with $\mathrm{dtm}$ are diamagnetic (Table II).

The electronic spectra of compounds 1-3 in acetone show a broad band in the region $17,540-18,510 \mathrm{~cm}^{-1}$ (Table II). It is characteristic of octahedral $\mathrm{Co}(\mathrm{II})$ complexes and can be assigned to the transition ${ }^{4} \mathrm{~T}_{1 \mathrm{~g}}(\mathrm{P}) \rightarrow{ }^{4} \mathrm{~T}_{1 \mathrm{~g}}$. Bands in the range $37,000-40,000 \mathrm{~cm}^{-1}$ are ascribed to $\pi-\pi^{*}$ transitions.

The electronic spectra of compounds 4-7 in acetone solutions display two bands in the range $15,600-17,800 \mathrm{~cm}^{-1}$ and $20,000-23,810 \mathrm{~cm}^{-1}$, which are characteristic of square planar complexes. These bands seem to correspond to the transitions ${ }^{1} \mathrm{~A}_{1 \mathrm{~g}} \rightarrow{ }^{1} \mathrm{~A}_{2 \mathrm{~g}}$ and ${ }^{1} \mathrm{~A}_{1 \mathrm{~g}} \rightarrow{ }^{1} \mathrm{~B}_{1 \mathrm{~g}}$ [9], respectively. According to recent studies on square planar $\mathrm{Ni}(\mathrm{II}) \mathrm{com}$ plexes [10] including $\mathrm{Ni}\left(\mathrm{Et}_{2} \mathrm{dtc}\right)_{2}$ and $\mathrm{Ni}\left(\mathrm{Et}_{2} \mathrm{dtp}\right)_{2}$ (where $\mathrm{Et}_{2} \mathrm{dtc}=\mathrm{Et}_{2} \mathrm{NCSS}^{-}$and $\mathrm{Et}_{2} \mathrm{dtp}=$ $(\mathrm{EtO})_{2} \mathrm{PSS}^{-}$), the two bands can be assigned to ${ }^{1} \mathrm{~A}_{1 \mathrm{~g}} \rightarrow{ }^{1} \mathrm{~B}_{1 \mathrm{~g}}\left(x^{2}-y^{2}, x y\right)$ and ${ }^{1} \mathrm{~A}_{1 \mathrm{~g}} \rightarrow{ }^{1} \mathrm{~B}_{1 \mathrm{~g}}\left(z^{2}, x y\right)$. In addition, bands at about $31,000 \mathrm{~cm}^{-1}$ can be considered as CT bands (maybe associated with $\mathrm{Ni} \rightarrow \mathrm{SC}-$ ). Compound 5 shows, further, a band at $41,660 \mathrm{~cm}^{-1}$ assignable to an intramolecular charge transfer in the dtc ligand of the type $\pi-\pi^{*}$ of the $\mathrm{N} \cdots \mathrm{C} \cdots \mathrm{S}$ group [11]. The electronic spectra are thus compatible with the diamagnetic nature of these complexes, and confirm their square planar structure. 


\begin{tabular}{|c|c|c|c|c|c|}
\hline No. & Complex & $\begin{array}{l}\mathrm{S}[\%] \\
\text { Found } \\
\text { (Calcd) }\end{array}$ & $\begin{array}{l}\mathrm{N}[\%] \\
\text { Found } \\
\text { (Calcd) }\end{array}$ & $\begin{array}{l}\text { m.p. } \\
\left({ }^{\circ} \mathrm{C}\right)\end{array}$ & $\begin{array}{l}\text { Yield } \\
{[\%]}\end{array}$ \\
\hline 1 & $\mathrm{Co}(\mathrm{Phdtcz})_{2}(\mathrm{Phtu})_{2}$ & $\begin{array}{c}26.22 \\
(26.35)\end{array}$ & $\begin{array}{c}15.29 \\
(15.35)\end{array}$ & 275 & 45 \\
\hline 2 & $\mathrm{Co}(\mathrm{Phdtcz})_{2}(\mathrm{Clphtu})_{2}$ & $\begin{array}{c}23.86 \\
(24.08)\end{array}$ & $\begin{array}{c}13.91 \\
(14.02)\end{array}$ & 245 & 55 \\
\hline 3 & $\mathrm{Co}(\mathrm{Phdtcz})_{2}(\mathrm{dtm})$ & $\begin{array}{c}21.90 \\
(22.01)\end{array}$ & $\begin{array}{c}6.37 \\
(6.41)\end{array}$ & 160 & 60 \\
\hline 4 & $\mathrm{Ni}\left(\mathrm{Et}_{2} \mathrm{dtc}\right)_{2}(\mathrm{dtm})$ & $\begin{array}{c}23.83 \\
(23.93)\end{array}$ & $\begin{array}{l}3.53 \\
(3.48)\end{array}$ & 170 & 80 \\
\hline 5 & $\mathrm{Ni}(\text { Phdtc })_{2}(\mathrm{dtm})$ & $\begin{array}{c}22.72 \\
(22.80)\end{array}$ & $\begin{array}{c}3.23 \\
(3.31)\end{array}$ & 175 & 70 \\
\hline 6 & $\mathrm{Ni}(p \text {-Toluiddtc })_{2}(\mathrm{dtm})$ & $\begin{array}{c}21.93 \\
(22.06)\end{array}$ & $\begin{array}{c}3.19 \\
(3.21)\end{array}$ & 170 & 60 \\
\hline 7 & $\mathrm{Ni}(\alpha-\mathrm{Naphdtc})_{2}(\mathrm{dtm})$ & $\begin{array}{c}20.24 \\
(20.38)\end{array}$ & $\begin{array}{c}2.85 \\
(2.96)\end{array}$ & 180 & 55 \\
\hline 8 & $\mathrm{Ni}(\mathrm{Phdtcz})\left(\mathrm{Et}_{2} \mathrm{dtcm}\right)$ & $\begin{array}{c}32.71 \\
(32.86)\end{array}$ & $\begin{array}{c}10.62 \\
(10.76)\end{array}$ & 200 & 65 \\
\hline
\end{tabular}

Table I. Analytical data and physical properties of the complexes.

Table II. Magnetic moments and electronic spectral data of the complexes (in $\mathrm{cm}^{-1}$ ).

\begin{tabular}{|c|c|c|c|}
\hline $\begin{array}{l}\text { Com- } \\
\text { pound }\end{array}$ & $v_{\max }$ & Assignment & $\begin{array}{l}\mu_{\text {eff }} \\
\text { (B.M.) }\end{array}$ \\
\hline 1 & $\begin{array}{l}18,510 \\
37,030\end{array}$ & $\begin{array}{l}{ }^{4} \mathrm{~T}_{1 \mathrm{~g}} \rightarrow{ }^{4} \mathrm{~T}_{1 \mathrm{~g}}(\mathrm{P}) \\
\pi \pi^{*}\end{array}$ & 3.81 \\
\hline 2 & $\begin{array}{l}18,180 \\
37,030\end{array}$ & $\begin{array}{l}{ }^{4} \mathrm{~T}_{1 \mathrm{~g}} \rightarrow{ }^{4} \mathrm{~T}_{1 \mathrm{~g}}(\mathrm{P}) \\
\pi-\pi^{*}\end{array}$ & 3.88 \\
\hline 3 & $\begin{array}{l}17,550 \\
40,000\end{array}$ & $\begin{array}{l}{ }^{4} \mathrm{~T}_{1 \mathrm{~g}} \rightarrow{ }^{4} \mathrm{~T}_{1 \mathrm{~g}}(\mathrm{P}) \\
\pi-\pi^{*}\end{array}$ & 3.82 \\
\hline 4 & $\begin{array}{l}15,870 \\
20,270 \\
30,580\end{array}$ & $\begin{array}{l}{ }^{1} \mathrm{~A}_{1 \mathrm{~g}} \rightarrow{ }^{1} \mathrm{~B}_{1 \mathrm{~g}}\left(x^{2}-y^{2}, x y\right) \\
{ }^{1} \mathrm{~A}_{1 \mathrm{~g}}{ }^{1} \mathrm{~B}_{1 \mathrm{~g}}\left(z^{2}, x y\right) \\
\mathrm{CT}\end{array}$ & Dia \\
\hline 5 & $\begin{array}{l}15,500 \\
- \\
31,940 \\
41,660\end{array}$ & $\begin{array}{l}{ }^{1} \mathrm{~A}_{1 \mathrm{~g}} \rightarrow{ }^{1} \mathrm{~B}_{1 \mathrm{~g}}\left(x^{2}-y^{2}, x y\right) \\
\overline{\mathrm{CT}} \\
\pi-\pi^{*}\end{array}$ & Dia \\
\hline 6 & $\begin{array}{l}15,625 \\
- \\
32,250\end{array}$ & $\begin{array}{l}{ }^{1} \mathrm{~A}_{1 \mathrm{~g}} \rightarrow{ }^{1} \mathrm{~B}_{1 \mathrm{~g}}\left(x^{2}-y^{2}, x y\right) \\
{ }_{\mathrm{CT}}\end{array}$ & Dia \\
\hline 7 & $\begin{array}{l}18,510 \\
31,250\end{array}$ & $\begin{array}{l}{ }^{1} \mathrm{~A}_{\mathrm{g}} \rightarrow{ }^{1} \mathrm{~B}_{1 \mathrm{~g}}\left(x^{2}-y^{2}, x y\right) \\
\mathrm{CT}\end{array}$ & Dia \\
\hline 8 & $\begin{array}{l}19,410 \\
23,350 \\
30,486\end{array}$ & $\begin{array}{l}{ }^{1} \mathrm{~A}_{\mathrm{g}} \rightarrow{ }^{1} \mathrm{~B}_{1 \mathrm{~g}}\left(x^{2}-y^{2}, x y\right) \\
{ }^{1} \mathrm{~A}_{\mathrm{g}} \rightarrow{ }^{1} \mathrm{~B}_{1 \mathrm{~g}}\left(z^{2}, x y\right) \\
\mathrm{CT}\end{array}$ & Dia \\
\hline
\end{tabular}

The IR spectra of compounds $\mathbf{1}$ and $\mathbf{2}$ show a splitting of $v$ CSS of the dithiocarbazate moiety, which may indicate a change of coordination mode of dithiocarbazate from $\mathrm{SS} \rightarrow \mathrm{SN}$ [2].
The IR spectrum of compound $\mathbf{3}$ shows a split band at 990 and $1020 \mathrm{~cm}^{-1}(v \mathrm{CSS})$ suggesting coordination of phenyldithiocarbazate ligands through $\mathrm{S}$ and $\mathrm{N}$ atoms. The bonding of $\mathrm{dtm}$ to the cobalt ion is evident by the red shift observed for $\nu \mathrm{P}=\mathrm{S}$ $\left(615-620 \mathrm{~cm}^{-1}\right)$ with respect to the free ligand $\left(628 \mathrm{~cm}^{-1}\right)$ [6]. The complex shows $\nu \operatorname{CoS}$ at 360 and $340 \mathrm{~cm}^{-1}$, and $\nu \mathrm{CN}$ at $1340 \mathrm{~cm}^{-1}$ (Table III).

Passing to $\mathrm{Ni}(\mathrm{II})$ dithiocarbamato mixed ligand complexes with $\mathrm{dtm}$, we have found that compounds 6 and 7 display $v$ CSS as a split band in the region $990-1010 \mathrm{~cm}^{-1}$, while compounds $\mathbf{4}$ and 5 exhibit in this frequency range a broad unresolved band, indicating the monodentate nature of the dithiocarbamate anion in these complexes. Furthermore, $\nu \mathrm{CN}$ appears in the range $1385-1435 \mathrm{~cm}^{-1}$ and at almost the same frequency as in the parent $\mathrm{Ni}$ (II) dithiocarbamato complexes. $\nu \mathrm{P}=\mathrm{S}$ occurs for these complexes in the $590-620 \mathrm{~cm}^{-1}$ region of the spectrum, indicating a metal-sulphur bonding. A band in the range $370-395 \mathrm{~cm}^{-1}$, which is sometimes associated with a shoulder (suggesting the presence of two types of $\mathrm{Ni}-\mathrm{S}$ bond), can be tentatively assigned as $v \mathrm{Ni}-\mathrm{S}$.

The X-ray powder diffraction patterns for compounds 4 and 5 (as representatives) indicate that these two mixed ligand complexes are nearly isomorphous with related phosphine mixed ligand complexes of dithiocarbamato $\mathrm{Ni}(\mathrm{II})$, for which square planar structures and monodentate dithiocarbamates have been suggested [12] (Table IV). 
Table III. Important IR bands of the complexes.

\begin{tabular}{lllllllrrr}
\hline & $\mathbf{1}$ & $\mathbf{2}$ & $\mathbf{3}$ & $\mathbf{4}$ & $\mathbf{5}$ & $\mathbf{6}$ & $\mathbf{7}$ & $\mathbf{8}$ \\
\hline$\nu \mathrm{CSS}$ & 1010,1030 & 1010,1030 & 1000,1020 & 1010 (broad) & 990 (broad) & 990,1010 & 990,1010 & 990 \\
$\nu \mathrm{CN}$ & 1360 & 1420 & 1340 & 1380 & 1400 & 1400 & 1305 & 1335,1350 \\
$\nu \mathrm{P}=\mathrm{S}$ & - & - & 615 & 600 & 590,610 & 620 & 620 & - \\
$\nu \mathrm{Cos}$ & - & - & 360,340 sh & - & - & - & - & 380,370 sh & 380 \\
$\nu \mathrm{NiS}$ & - & - & - & 385,375 sh & 380,370 sh & 385 & \\
\hline
\end{tabular}

Table IV. X-ray powder patterns (d-spacings, $\AA)^{\mathrm{a}}$.

\begin{tabular}{lccc}
\hline $\mathrm{Ni}\left(\mathrm{Et}_{2} \mathrm{dtc}\right)_{2}(\mathrm{dtm})$ & $\mathrm{Ni}(\mathrm{Phdtc})_{2}(\mathrm{dtm})$ & $\mathrm{Ni}(\alpha \text {-naphdtc })_{2}(\mathrm{dpp})_{2}{ }^{\mathrm{b}}$ & $\mathrm{Ni}(\mathrm{Phdtc})_{2}(\mathrm{dpe})_{2}{ }^{\mathrm{b}}$ \\
\hline $10.6 \mathrm{~s}$ & $11.1 \mathrm{~s}$ & $11.05 \mathrm{vs}$ & - \\
$9.2 \mathrm{w}$ & - & - & $9.8 \mathrm{w}$ \\
$8.1 \mathrm{vs}$ & $8.2 \mathrm{~m}$ & $8.8 \mathrm{w}$ & $7.3 \mathrm{~m}$ \\
$7.1 \mathrm{w}$ & $7.1 \mathrm{w}$ & - & $6.8 \mathrm{w}$ \\
$6.3 \mathrm{w}$ & $6.5 \mathrm{w}$ & $6.8 \mathrm{w}$ & $6.3 \mathrm{w}$ \\
$5.8 \mathrm{w}$ & $5.3 \mathrm{w}$ & $5.9 \mathrm{w}$ & $5.5 \mathrm{w}$ \\
$5.1 \mathrm{~m}$ & $4.9 \mathrm{w}$ & $4.4 \mathrm{~m}$ & $4.6 \mathrm{~s}$ \\
$4.6 \mathrm{w}$ & $4.6 \mathrm{w}$ & $4.2 \mathrm{~s}$ & $4.4 \mathrm{~m}$ \\
$4.1 \mathrm{w}$ & $4.3 \mathrm{w}$ & - & $4.2 \mathrm{w}$ \\
$4.0 \mathrm{w}$ & $4.1 \mathrm{w}$ & $3.7 \mathrm{w}$ & $4.0 \mathrm{w}$ \\
\hline
\end{tabular}

${ }^{a}$ Intensities were estimated visually;

${ }^{\mathrm{b}}$ from reference [12]; dpe = bis(diphenylphosphino)ethane; dpp = bis(diphenylphosphino)propane.

We have attempted to prepare a mixed ligand complex from the interaction of sodium diethyldithiocarbamate and bis(phenyldithiocarbazato)nickel(II), but only the dithiocarbamate complex was obtained as the final product:

\section{$\mathrm{NaEt}_{2} \mathrm{NCSS}+\mathrm{Ni}(\mathrm{PhNHNHCSS})_{2}+\rightarrow$ $\mathrm{Ni}\left(\mathrm{Et}_{2} \mathrm{NCSS}\right)(\mathrm{PhNHNHCSS})+\mathrm{NaPhNHNHCSS}$ \\ $2 \mathrm{NaEt}_{2} \mathrm{NCSS}+\mathrm{Ni}(\mathrm{PhNHNHCSS})_{2} \rightarrow$ $\mathrm{Ni}\left(\mathrm{Et}_{2} \mathrm{NCSS}\right)_{2}+2 \mathrm{NaPhNHNHCSS}$}

The resulting complex is identified on the basis of microanalysis, IR and electronic spectra. The mixed ligand complex could, however, be obtained through the reaction of bis(diethyldithiocarbamato)nickel(II) and bis(phenyldithiocarbazato)nickel(II).

$\mathrm{Ni}\left(\mathrm{Et}_{2} \mathrm{NCSS}\right)_{2}+\mathrm{Ni}(\mathrm{PhNHNHCSS})_{2} \rightarrow$ $2 \mathrm{Ni}\left(\mathrm{Et}_{2} \mathrm{NCSS}\right)(\mathrm{PhNHNHCSS})$

This complex has been proved to be diamagnetic. The acetone solution of the complex shows two $d-d$ bands in its electronic spectrum at 19,410 and $23,250 \mathrm{~cm}^{-1}$; the position and shape of the bands is typical of a square planar stereochemistry. The two bands are shifted to higher energies as compared with those of bis(diethyldithiocarbamato)nickel(II) or bis(phenyldithiocarbazato)nickel(II) in acetone.

The IR spectrum exhibits the characteristics of both diethyldithiocarbamate and dithiocarbazate anions. Thus the mixed ligand complex shows two bands at $1350 \mathrm{~cm}^{-1}$ and $1335 \mathrm{~cm}^{-1}$ (shoulder), which correspond to $\nu \mathrm{CN}$ of dithiocarbazate [1] and dithiocarbamate [13], respectively. The band of medium intensity observed at $990 \mathrm{~cm}^{-1}$ is assigned to the $\mathrm{C}=\mathrm{S}$ stretching vibration. Of particular importance are the bands in the range $2830-2960 \mathrm{~cm}^{-1}$ and $680-700 \mathrm{~cm}^{-1}$, which correspond to $\nu \mathrm{CH}-$ stretching vibrations of the ethyl groups of diethyldithiocarbamate and the frequencies of the monosubstituted phenyl group of the phenyldithiocarbazate moiety, respectively.

The biological activities of some of the mixed ligand complexes were tested against a number of bacteria $v z$., E. coli, St. albus, M. loteus, and B. subtilis. Compounds $\mathbf{1}$ and $\mathbf{5}$ show variable anti- 
bacterial activities against the test bacteria, but with compounds 3, 4 and 6 no reaction is observed (Table V).

Table V. Antimicrobial screening of some of the complexes.

\begin{tabular}{llllll}
\hline Test bacteria & $\mathbf{1}$ & $\mathbf{3}$ & $\mathbf{4}$ & $\mathbf{5}$ & $\mathbf{6}$ \\
\hline E. coli & ++ & - & - & - & - \\
St. albus & + & - & - & + & - \\
M. loteus & +++ & - & - & - & - \\
B. subtilis & +++ & - & - & + & - \\
\hline
\end{tabular}

Weak + ; Medium ++ ; Strong +++ ; Resistant - .

\section{Experimental}

Bis(phenyldithiocarbazato)cobalt(II), bis(phenyldithiocarbazato)nickel(II) [1], bis(diethyldithiocarbamato)nickel(II) [14], bis(phenyldithiocarbamato)nickel(II), bis( $p$-toluidinedithiocarbamato)nickel(II) [15], bis( $\alpha$-naphthyldithiocarbamato)nickel(II) [13], and bis(diphenylphosphinothioyl)methane [16] were prepared according to literature procedures.

\section{$\mathrm{Co}(\mathrm{Phdtcz})_{2}(\mathrm{Phtu})_{2}$ and $\mathrm{Co}(\mathrm{Phdtcz})_{2}(\mathrm{Clphtu})_{2}$}

A solution of $0.33 \mathrm{~g}(2.4 \mathrm{mmole})$ phenylthiourea in ethanol was added to a solution of $0.5 \mathrm{~g}$ (1.2 mmole) bis(phenyldithiocarbazato)cobalt(II) in acetone. This mixture was refluxed for about $3 \mathrm{~h}$. A black precipitate was formed, which was filtered, washed with ethanol and dried in vacuo over $\mathrm{P}_{2} \mathrm{O}_{5}$. In a similar manner $\mathrm{Co}(\mathrm{Phdtcz})_{2}(\mathrm{Clphtu})_{2}$ was prepared.

\section{$\mathrm{Co}(\mathrm{Phdtcz})_{2}(\mathrm{dtm})$}

An alcoholic solution containing $0.53 \mathrm{~g}$ (1.2 mmole) bis(diphenylphosphinothioyl)methane was added dropwise with stirring to a solution of $0.5 \mathrm{~g}$ (1.2 mmole) bis(phenyldithiocarbazato)cobalt(II) in ethanol. The mixture was refluxed for $2 \mathrm{~h}$ whereupon a brown precipitate was formed, which was filtered, washed with alcohol and then dried in vacuo over $\mathrm{P}_{2} \mathrm{O}_{5}$.
General method for the preparation of dithiocarbamato nickel(II) complexes with dtm

The preparation of the complexes was achieved via the following procedure: A chloroform solution of bis(diphenylphosphinothioyl)methane (1.2 mmole) was added dropwise under continuous stirring to an equivalent amount of a chloroform solution of the dithiocarbamato nickel(II) complex (1.2 mmole). The mixture was left stirring at room temperature for $3 \mathrm{~h}$, concentrated by slow evaporation of the solvent followed by standing overnight. The dark to pale green crystals (violet in case of compound 7) were filtered, washed with little chloroform, and dried in vacuo over $\mathrm{P}_{2} \mathrm{O}_{5}$.

\section{$\mathrm{Ni}\left(E t_{2} d t c\right)(P d h t c z)$}

A chloroform solution of bis(phenyldithiocarbazato)nickel(II) (2.4 mmole) was mixed with a chloroform solution of bis(diethyldithiocarbamato)nickel(II) (2.4 mmole), and the mixture was refluxed for $5 \mathrm{~h}$. Concentrating the solution to about one third of the volume produced a dark brown product (almost black), which was filtered, washed with little chloroform, and dried in vacuo over $\mathrm{P}_{2} \mathrm{O}_{5}$.

\section{Reaction of $\mathrm{Ni}(\mathrm{Phdtcz})_{2}$ and $\mathrm{NaEt}_{2} d t c$}

An ethanolic solution of $\mathrm{Ni}(\mathrm{Phdtcz})_{2}$ was treated with sodium diethyldithiocarbamate dissolved in ethanol (1:1 mole ratio), and the mixture refluxed for $2 \mathrm{~h}$. The green precipitate was filtered, washed with little ethanol, and dried in vacuo over $\mathrm{P}_{2} \mathrm{O}_{5}$.

\section{Physical measurements}

The conductivity in DMF solutions was measured with an LF Digi 550 conductance bridge at $25^{\circ} \mathrm{C}$. The magnetic moments were obtained with the Gouy balance using $\mathrm{Co}\left[\mathrm{Hg}(\mathrm{NCS})_{4}\right]$ as the calibrant. Electronic spectra in solution were recorded on a Shimadzu UV-200S spectrophotometer. The infrared spectra in the range $4000-200 \mathrm{~cm}^{-1}$ were measured in $\mathrm{KBr}$ pellets on a Perkin Elmer 599 B spectrophotometer. Powder diffraction patterns were recorded on a Shimadzu X-ray diffraction unit with a $\mathrm{CuK}_{\alpha}$ target $(\lambda=1.54 \AA)$.

The authors are very grateful to Prof. Dr. H. Schmidbaur, Anorganisch-Chemisches Institut der Technischen Universität München, for revising the manuscript. 
[1] B. B. Kaul and K. B. Pandeya, J. Inorg. Nucl. Chem. 40, 1035 (1978); and references therein.

[2] A. A. M. Aly, M. M. Kamal, M. S. El Meligy, and A. I. El Said, Z. Naturforsch. 39b, 1676 (1984); and references therein.

[3] a) G. A. Katsoulos, G. E. Manoussakis, and C. A. Isipis, Polyhedron 3, 735 (1984);

b) R. Schierl, U. Nagel, and W. Beck, Z. Naturforsch. 39b, 649 (1984);

c) K. J. Cavell, R. J. Magee, and J. O. Hill, J. Inorg. Nucl. Chem. 41, 1281 (1979);

d) W. Beck, M. Girnth, M. Castillo, and H. Zippel, Chem. Ber. 111, 1246 (1978).

[4] S. O. Grim, S. Nittolo, N. L. Ammon, P. H. Smith, I. J. Colquhoud, and W. McFarlane, Inorg. Chim. Acta 77, L, 241 (1983).

[5] E. W. Ainscough and A. M. Brodie, Coord. Chem. Rev. 27, 59 (1978) and references therein.

[6] E. W. Ainscough, H. A. Bergen, and M. Brodie, J. Chem. Soc. Dalton 1976, 1649.
[7] W. J. Geary, Coord. Chem. Rev. 7, 81 (1971).

[8] Modern Coordination Chemistry, Interscience Publishers Ltd., London 1960, p. 406.

[9] A. B. P. Lever, Inorganic Electronic Spectroscopy, Elsevier, Amsterdam 1968

[10] M. A. Atanassov and G. St. Nikolov, Inorg. Chim. Acta 68, 15 (1983).

[11] G. C. Franchini, A. Giusti, C. Preti, L. Tassia, and P. Zannini, Polyhedron 4, 1553 (1985).

[12] A. A. M. Aly, A. A. Mohamed, M. A. Mousa, and M. El-Shabasy, Chem. Scripta 24, 196 (1984).

[13] B. B. Kaul and K. B. Pandeya, J. Inorg. Nucl. Chem. 40, 229 (1978).

[14] M. Umar Fayyaz and M. W. Grant, Aust. J. Chem. 32, 2159 (1979).

[15] D. Coucouvanis and J. P. Fackler (Jr.), Inorg. Chem. 6, 2047 (1967)

[16] W. E. Slinkard and D. W. Meek, J. Chem. Soc. Dalton 1973, 1024. 